\title{
Unsaturated shear strength properties of a compacted expansive soil from Regina, Canada
}

\author{
Rashedul H. Chowdhury ${ }^{1}$ - Shahid Azam²
}

Received: 30 August 2016/Accepted: 15 November 2016/Published online: 24 November 2016

(C) Springer International Publishing Switzerland 2016

\begin{abstract}
The main objective of this research was to investigate the unsaturated shear strength properties of the compacted expansive soil from Regina (Saskatchewan, Canada). Laboratory investigations on a typical expansive clay (liquid limit of $77 \%$ and plastic limit of $27 \%$ ) were conducted using both saturated and unsaturated samples. Results indicated that the SWCC had one AEV of $10 \mathrm{kPa}$ for $w$ and $\theta$ and two AEVs for $S: 10$ and $7000 \mathrm{kPa}$ due to drainage through inter-clod pores and soil matrix, respectively. Most of the shrinkage occurred around $S \approx 80 \%$, whereas desaturation before and after this value was associated with small changes in void ratio. Likewise, the peak stress on the dry side of optimum along with the initial gradient of the stress-displacement curve of up to $250 \mathrm{kPa}$ and $13,350 \mathrm{kPa} / \mathrm{mm}$, respectively, decreased to $170 \mathrm{kPa}$ and $5670 \mathrm{kPa} / \mathrm{mm}$ on the wet side of optimum. The variation in cohesion followed the compaction curve and increased from $24 \mathrm{kPa}$ on dry side to $65 \mathrm{kPa}$ at optimum and then decreased to $33 \mathrm{kPa}$ on wet side. The friction angle followed an L-shaped trend and decreased from $44^{\circ}$ on dry side to $29^{\circ}$ at optimum and to $27^{\circ}$ on wet side. Finally, the S-shaped $\phi^{\mathrm{b}}$ curve was in agreement with compaction characteristics and the SWCC. The $\phi^{\mathrm{b}}$ curve comprised $1^{\circ}$ increase on dry side (and approaching residual suction), $12^{\circ}$ increase around optimum (between
\end{abstract}

Shahid Azam

Shahid.Azam@URegina.CA

1 Clifton Associated Limited, 340 Maxwell Crescent, Regina, SK S4N 5Y5, Canada

2 Environmental Systems Engineering, Faculty of Engineering and Applied Science, University of Regina, 3737 Wascana Parkway, Regina, SK S4S 0A2, Canada
$\mathrm{AEV}$ and residual suction), and $2^{\circ}$ increase on wet side that tended to approach $\phi$ near saturation.

Keywords Expansive soils - Compaction curve $\cdot$ Shear strength $\cdot$ Unsaturated soils

\section{Introduction}

Expansive soils are characterized by the presence of high amount of specific clay minerals. The shear strength parameters of these clayey soils are mainly affected by the initial water content as well as drainage and saturation conditions. In general, the expansive clays have low friction (depending on the amount of coarse particles), high cohesion (due to water adsorption by clay minerals), and significant apparent cohesion (due to water retention in a fine-grained soil matrix). In general, shear strength is improved by compaction to ensure that the soils are adequate for construction purposes. This is particularly true for the expansive soil in Regina (Saskatchewan, Canada), where good quality borrow materials are not readily available. Typical case studies, as reported in the literature, include Panesar et al. [49] and Widger and Fredlund [66]. Although chemical admixtures (such as lime [58] and calcium chloride [17]) have been tried for soil stabilization, their use is largely precluded because of the harsh local climatic conditions and the use of de-icing salts in winter. Furthermore, Regina is going through a significant infrastructure construction activity. Large-scale projects in the provincial capital include the Global Transportation Hub, the Regina bypass, and new residential zones. The shear strength properties are extensively used in: (i) evaluation of stability of raised or excavated slopes for embankments; (ii) design of earth retaining structures for bridges and 
interchanges; and (iii) assessment of bearing capacity of strip, mat, and pile foundations for buildings. To ensure stability of the constructed facilities, there is a need to understand the shear strength properties of the local compacted expansive soil.

The shear strength properties [friction angle $\left(\phi^{\prime}\right)$, cohesion $\left(c^{\prime}\right)$, and friction angle due to suction $\left.\left(\phi^{\mathrm{b}}\right)\right]$ of compacted soils are determined using the theory of unsaturated soil mechanics. Laboratory investigations either use unsaturated samples for simultaneous measurement of all parameters in the same test [14] or saturated samples for measuring $\phi^{\prime}$ and $c^{\prime}$ with $\phi^{\mathrm{b}}$ estimated from soil water characteristic curve (SWCC) [65]. These approaches are hampered by time requirement, apparatus modification, and testing expertise. Practitioners require a quick (eliminating saturation time) and simple (precluding equipment changes) method to determine shear strength properties of the local expansive soil over a wide suction range. This study proposes an approach that uses compacted (unsaturated) samples to determine friction angle and cohesion and measures soil suction to determine $\phi^{\mathrm{b}}$ (from the extended failure envelope, as given by Fredlund et al. [23]). $\phi^{\mathrm{b}}$ is verified through estimation by the method of Vanapalli et al. [65] extended to the expansive Regina clay.

The main purpose of this paper is to investigate the unsaturated shear strength properties of the compacted expansive soil. Geotechnical index properties were determined for initial soil assessment, whereas the compaction curve was determined to identify appropriate test samples. The SWCC along with shrinkage curve were determined to understand water retention and volume change of the soil and for subsequent analyses. The direct shear tests were conducted to understand the variation of shear strength properties with water content and soil suction.

\section{Literature review}

Figure 1 shows the shear strength failure envelopes for soils. Denoting shear stress at failure by $\tau_{\mathrm{f}}$, effective cohesion by $c^{\prime}$, total normal stress at failure by $\sigma_{\mathrm{n}}$, effective normal stress at failure by $\left(\sigma_{\mathrm{n}}-u_{\mathrm{w}}\right)_{\mathrm{f}}$, pore-water pressure at failure by $u_{\mathrm{w}}$, and effective friction angle by $\phi^{\prime}$, the failure criterion for saturated soils (Fig. 1a) is given by the following expression [61]:

$\tau_{\mathbf{f}}=c^{\prime}+\left(\sigma_{\mathbf{n}}-u_{w}\right)_{f} \tan \phi^{\prime}$.

Fredlund et al. [23] extended the above failure envelop to unsaturated soils (Fig. 1b) by denoting suction at failure by $\left(u_{\mathrm{a}}-u_{\mathrm{w}}\right)_{\mathrm{f}}$ and the slope of the envelop along the suction axis by $\phi^{\mathrm{b}}$, as described by the following equation:

$\tau_{\mathbf{f}}=c^{\prime}+\left(\sigma_{\mathbf{n}}-u_{\mathrm{w}}\right)_{\mathrm{f}} \tan \phi^{\prime}+\left(u_{\mathrm{a}}-u_{\mathrm{w}}\right)_{\mathrm{f}} \tan \phi^{\mathrm{b}}$.

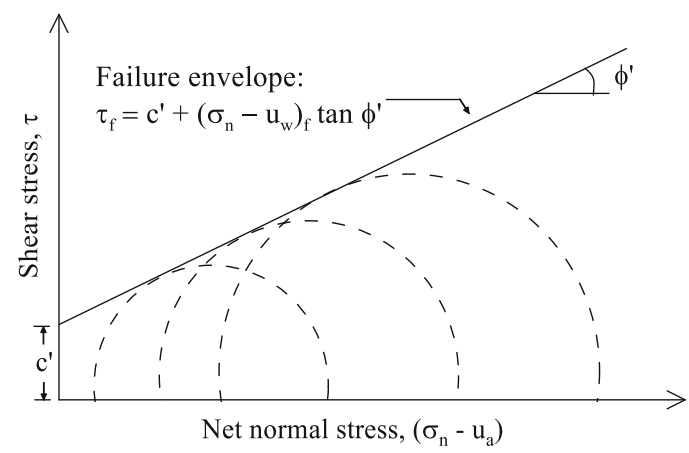

(a) Saturated soils

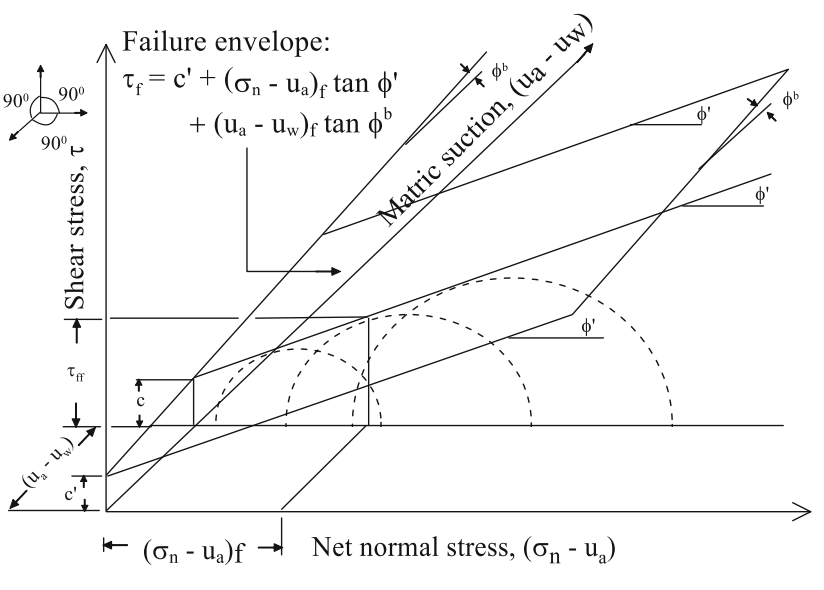

(b) Unsaturated soils

Fig. 1 Failure criteria for soils: a saturated soils and b unsaturated soils (after [23])

Equation 2 assumes a constant $\phi^{\mathrm{b}}$ as shown by the planar graph in Fig. 1b. A different equation is not required to capture the effect of variable $\phi^{\mathrm{b}}$. Instead, the failure envelope can be linearized by translating the portion corresponding to lower soil suctions onto the shear stress versus net normal stress plane [25].

The shear strength properties of unsaturated cohesive soils can be determined by controlling suction and shearing the sample in a modified apparatus, such as the modified triaxial test [14], the use of axis translation in the modified triaxial test [31], the modified ring shear test [53], and the modified direct shear test [26]. Miao et al. [44] customized the triaxial test to capture volume changes of natural expansive clays (Guangxi, China) and concluded that these variations arise from microstructural re-adjustment during shearing. A similar approach was adopted by Zhan and $\mathrm{Ng}$ [69] to include dilation of expansive clays (Hubei, China) in the direct shear test. Furthermore, $\mathrm{Ng}$ et al. [47] compared triaxial test results on compacted expansive clays (Zaoyang, China) while separately controlling matric suction by axis translation and osmotic techniques. No difference was observed in the measured values of $\phi$, whereas 
$\phi^{\mathrm{b}}$ was found to be up to $4^{\circ}$ higher when determined by the former method. Katte and Blight [37] showed that changes in osmotic suction have negligible influence on the shear strength parameters of compacted limestone powder. Overall, the modifications of the apparatus are expensive, the shear strength testing requires experience, and the entire testing process is time-consuming especially when volume is measured. To overcome these disadvantages, the alternative approach is to separately determine soil suction and shear strength of expansive soils. For example, Bai and Liu [11] measured matric suction using the filter paper method and shear strength parameters using a conventional direct shear test. The current paper extends the above study using a potentiameter to measure total suction.

Several indirect methods have been proposed to determine the saturated shear strength parameters in a conventional apparatus and using the SWCC to estimate $\phi^{\mathrm{b}}$ $[12,38,48,52,60]$. A simple equation to estimate the friction angle due to suction $\left(\phi^{\mathrm{b}}\right)$ is given as follows [65]:

$\tan \phi^{\mathrm{b}}=\left(\theta_{\mathrm{w}} / \theta_{\mathrm{s}}\right)^{\kappa} \tan \phi^{\prime}$.

The above equation uses the SWCC to obtain the volumetric water content $\left(\theta_{\mathrm{w}}=\right.$ product of gravimetric water content, $w$, and dry unit weight, $\left.\gamma_{\mathrm{d}}\right)$ and the saturated volumetric water content $\left(\theta_{\mathrm{s}}\right)$, a fitting parameter $(\kappa)$, and the friction angle $\phi^{\prime}$ determined under saturated conditions. Ye et al. [68] recently concluded that the above equation is best suited for weak expansive clays. This study utilizes Eq. 3 in conjunction with Fig. 2 [plot of the fitting parameter, $\kappa$, as a function of the plasticity index (Ip)] to verify the measured $\phi^{\mathrm{b}}$. The current figure presents published data and the best-fit curve for an Ip of up to $35 \%$, as developed by Vanapalli and Fredlund [64]. The best-fit equation resulted in $\kappa=2.90$ for Regina clay (Ip $=50 \%$, as reported later in this paper). Furthermore, the curve for compacted clays based on data

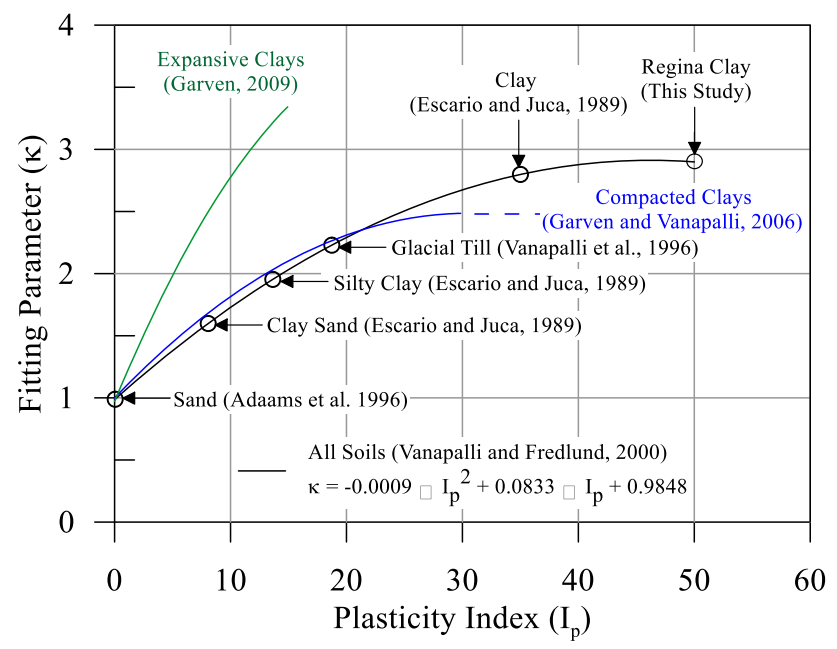

Fig. 2 Fitting parameter versus plasticity index (after [64]) with an Ip of up to 25\% (Garven and Vanapalli [29] was found to match quite well with the above-mentioned best-fit equation and is assumed to be horizontal beyond an Ip of $30 \%$. In contrast, the curve for expansive clays was developed for an Ip $=15 \%$ [28]. Therefore, the current study used the best-fit equation of Vanapalli and Fredlund [64] which was closest to the Ip of the investigated Regina clay.

Table 1 summarizes the measured shear strength parameters of unsaturated cohesive soils with various degrees of expansiveness. The geotechnical index properties have also been reported for preliminary soil assessment. Several compositional and environmental factors as well as test conditions affect the shear strength properties of this class of sedimentary soils. All the shear parameters are usually high when measured using the triaxial test compared with those from the direct shear test [13]. Previous work has shown that the latter test is very practical for unsaturated soils owing to short sample drainage, despite issues with stress concentrations, pre-defined failure plane, and rotation of principal stresses. The table indicates that the higher the water adsorbing capacity (indicated by the high consistency limits), the higher the cohesion, and the lower the friction [56, 57]. This should be attributed to swelling of the sample due to clay hydration and the associated changes in soil microstructure [41]. Likewise, an increase in water content generally results in a decrease in friction angle and an increase in cohesion: a clearly discernible trend does not exist for variations in dry unit weight. Whereas $\phi^{\mathrm{b}}$ is not usually measured, its value approaches $\phi^{\prime}$ at low suction (near saturation). Cokca et al. [16] attributed the high friction angle measured for Ankara clay to a low water content (high suction) of the sample. The current paper applies the theory of unsaturated soil mechanics to compacted expansive clays and develops a physical understanding of the shear strength properties of such soils.

\section{Laboratory investigations}

The expansive Regina clay was obtained from a local pit in accordance with ASTM D1452-09 [2]. The soil originated from pro-glacial deposition of fine-grained materials and underwent weathering at controlled drainage in a semi-arid climate [15]. This environment supported the development of active clay minerals (such as smectite, hydrous mica, and chlorite) in the soil, and, as such, the present day sediment exhibits high water adsorption and retention [36]. The samples were retrieved in sealed containers and transported to the Geotechnical Testing Laboratory at the University of Regina for storage at $21{ }^{\circ} \mathrm{C}$.

The specific gravity $\left(G_{\mathrm{s}}\right)$ and consistency limits were determined according to ASTM D854-10 [1] and ASTM 
Table 1 Shear strength parameters of unsaturated cohesive soils with various degrees of expansiveness

\begin{tabular}{|c|c|c|c|c|c|c|c|c|}
\hline References & Material & $w_{1}(\%)$ & $w_{\mathrm{p}}(\%)$ & $w(\%)$ & $\gamma_{\mathrm{d}}\left(\mathrm{kN} / \mathrm{m}^{3}\right)$ & $c^{\prime}(\mathrm{kPa})$ & $\phi^{\prime}\left({ }^{\circ}\right)$ & $\phi^{\mathrm{b}}\left({ }^{\circ}\right)$ \\
\hline \multicolumn{9}{|c|}{ Suction controlled triaxial shear test } \\
\hline Ye et al. [68] & Hubei clay & 42 & 24 & 21 & 19.7 & 77 & 24.6 & $17.6(\psi=100 \mathrm{kPa})$ \\
\hline Miao et al. [44] & Guangxi clay & 61 & 30 & - & 14.5 & 90 & 19.5 & - \\
\hline $\mathrm{Ng}$ et al. [47] & Zaoyong clay & 68 & 29 & 30 & 13.7 & 21 & 20 & 17 \\
\hline Rahadrjo et al. [51] & Jurong clay & 36 & 22 & 16 & 16.8 & 80 & 31.5 & $29(\psi=50 \mathrm{kPa})$ \\
\hline Taha et al. [59] & Residual clay & - & - & 21 & 13.5 & 58 & 26.5 & 17.8 \\
\hline \multicolumn{9}{|c|}{ Suction controlled direct shear test } \\
\hline Nam et al. [46] & Riverbank soil & 40 & 22 & 31 & 17.4 & 28 & 22.5 & $16(\psi<100 \mathrm{kPa})$ \\
\hline Huat et al. [34] & Residual soil & 95 & 45 & - & - & 150 & 29.4 & $13(\psi=150 \mathrm{kPa})$ \\
\hline Miao et al. [45] & Nanyang clay & 59 & 27 & 21 & 16.0 & 32 & 21.3 & 21 \\
\hline Gan and Fredlund [26] & Glacial till & 36 & 17 & 16 & 17.8 & 10 & 25.5 & $20.5(\psi=100 \mathrm{kPa})$ \\
\hline \multicolumn{9}{|c|}{ Conventional direct shear test } \\
\hline Bai and Liu [11] & Nanyang clay & 50 & 27 & 18 & 15.7 & 179 & 19.2 & $9.5(\psi=400 \mathrm{kPa})$ \\
\hline Yang et al. [67] & Ningming clay & 60 & 27 & 23 & 12.8 & 36 & 15.6 & - \\
\hline Cokca et al. [16] & Ankara clay & 56 & 23 & 18 & 14.4 & 40 & 44 & $(\psi=2059 \mathrm{kPa})$ \\
\hline Kong and Tan [39] & Hubei clay & 82 & 35 & 29 & 18.3 & 92 & 10.4 & - \\
\hline Shanker et al. [54] & Black cotton soil & 63 & 24 & 10 & 14.1 & 4 & 21 & - \\
\hline
\end{tabular}

D4318-10 [7], respectively, and the clay was classified using ASTM D2487-11 [5]. Likewise, the compaction test was conducted as per ASTM D1557-12 [3]. The pulverized dry clay was sieved to obtain material finer than $0.425 \mathrm{~mm}$. Pre-determined amounts of water and clay were mixed, allowed to equilibrate for $24 \mathrm{~h}$ in plastic bags, and dynamically compacted in three layers thereafter. The gravimetric water content $(w)$ was determined according to ASTM D2216-10 [4] and used in conjunction with the measured sample weight and volume to determine the dry unit weight $\left(\gamma_{\mathrm{d}}\right)$ using phase relationships.

The drying SWCC was determined according to ASTM D6836-02 [9] using $10 \mathrm{~mm}$ thick and $40 \mathrm{~mm}$ round specimens cored through a compacted sample on the wet side $\left(w=30 \%\right.$ and $\left.\gamma_{\mathrm{d}}=14.5 \mathrm{kN} / \mathrm{m}^{3}\right)$ to minimize hysteresis during pre-wetting [10]. The specimens were put in circular rings, placed on appropriate pre-saturated porous plate/cellulose membrane, and allowed to saturate in a bathtub thereby achieving $w=46 \%$ and $\gamma_{\mathrm{d}}=11 \mathrm{kN} / \mathrm{m}^{3}$. Known suctions were applied using a pressure plate extractor for values between 5 and $450 \mathrm{kPa}$ and pressure membrane extractor for values between 450 and $1000 \mathrm{kPa}$. The air-water interface in the graduated burette was regularly monitored, and the test was terminated when the change in readings was negligible over a $96 \mathrm{~h}$. The measured $w$ was converted to $\theta$ and $S$ using volume measurements on duplicate samples (described later in the shrinkage test) and appropriate phase relationships.

The dew point potentiameter (WP4-T) was used to measure suction values $(2500 \mathrm{kPa}$ to about $70,000 \mathrm{kPa})$. About $5 \mathrm{mg}$ material was put in the sampling cup to ensure accurate measurement [40]. The sample was put in the measurement chamber and was allowed to equilibrate with the adjacent air. The device calculated suction $[\psi=R T /$ $M$ ln (RH)] using the universal gas constant, $R(8.145 \mathrm{~J} / \mathrm{mol}-\mathrm{K})$, sample temperature, $T(\mathrm{~K})$, water molecular mass, $M(18.01 \mathrm{~g} / \mathrm{mol})$, and the chamber relative humidity (RH). The water content of the samples was also measured, and the values were converted to other index properties, as described earlier.

The shrinkage test was conducted according to ASTM D4943-08 [8] using the water displacement method for volume measurement. The duplicate specimens (prepared similar to those for the pressure extractor test) were coated with molten wax (specific gravity $=0.9$ ) and allowed to solidify at $21{ }^{\circ} \mathrm{C}$. Each sample was submerged in a $250 \mathrm{~mL}$ graduated cylinder, and the water height was measured. The displaced water was removed in a graduated syringe, its mass determined using a scale balance, and the quantity converted to water volume that pertained to the volume of the wax-coated clay. The soil volume was obtained by subtracting the volume of wax-coated sample from that of the wax (mass/0.9), and the result was corrected to account for air entrapment at the clay-wax interface [50]. The sample mass was also measured for determination of bulk unit weight and void ratio from phase relationships.

Figure 3 gives the direct shear test setup. The singlestage consolidated drained test was conducted as per ASTM D3080/D3080M-11 [6] using $29 \mathrm{~mm}$ thick and $102 \mathrm{~mm}$ round samples cut from the compacted soil. The samples were placed in the shear box assembly (Humboldt 2560A Pneumatic direct/residual shear apparatus) between 


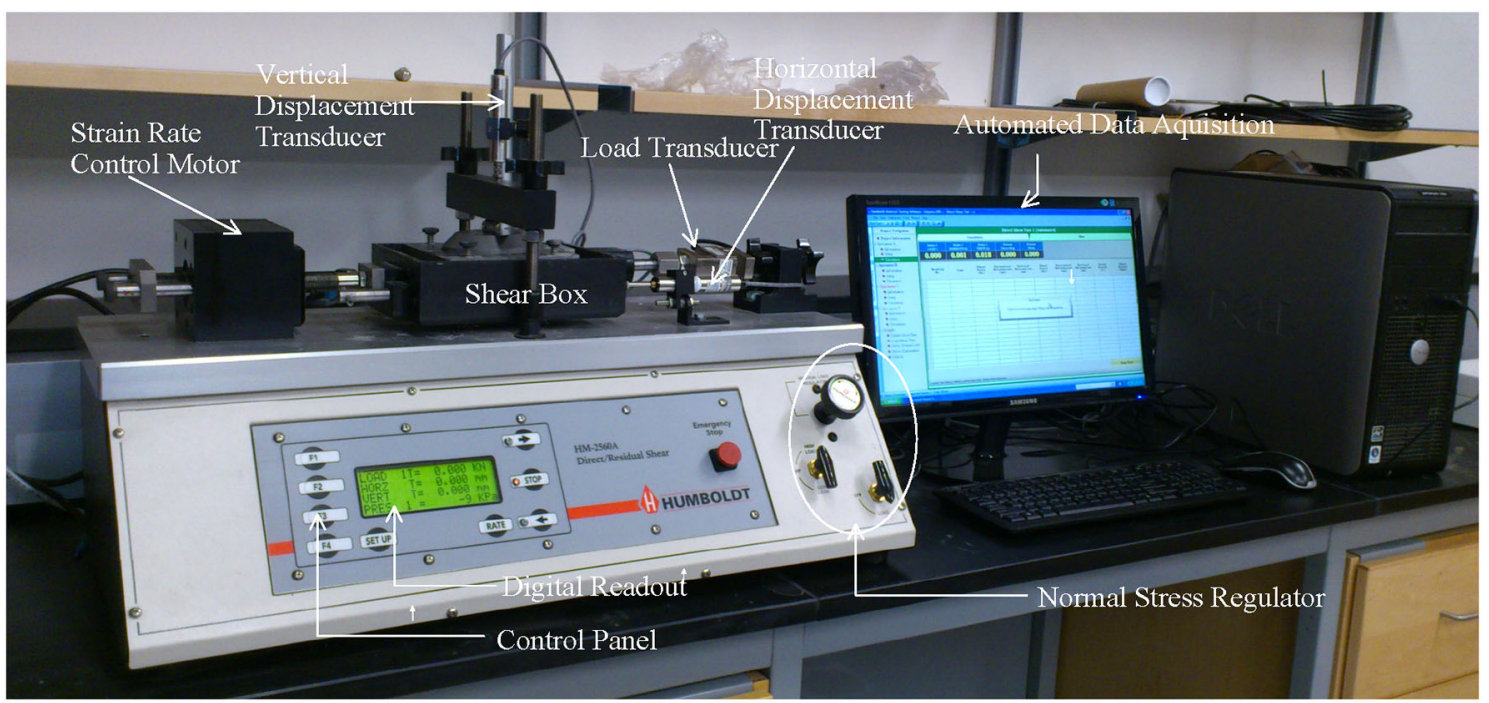

(a) Test setup

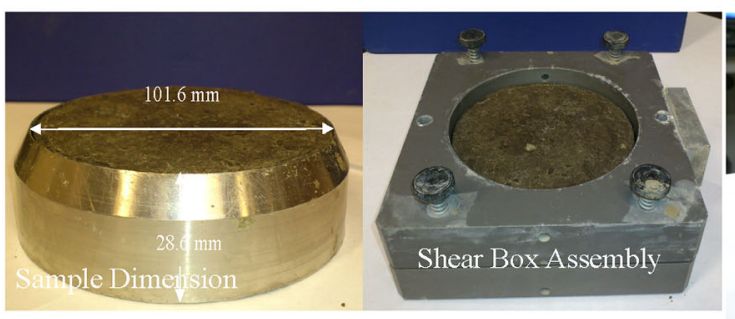

(b) Sample before test

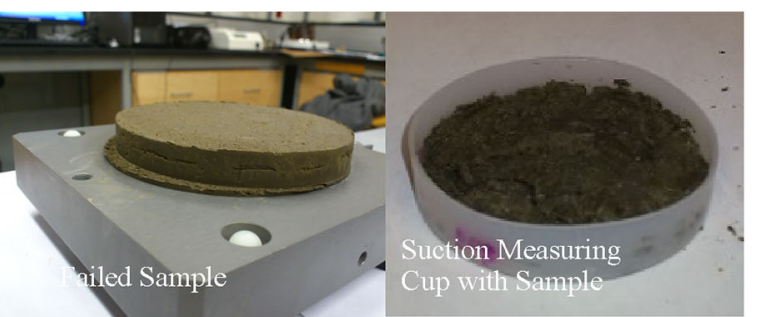

(c) Sample after test

Fig. 3 Direct shear testing: a test setup; b sample before test; and c sample after test

two pre-saturated ceramic porous stones with a high air entry value $(300 \mathrm{kPa})$, thereby minimizing suction variation during the test. Furthermore, the individual samples were allowed to equilibrate under their corresponding net normal stresses $(75,150$, and $250 \mathrm{kPa})$ for up to $24 \mathrm{~h}$ to cancel volumetric strains and potential soil suction changes. Finally, the shear box was covered with saran wrap (not shown in Fig. 3), and the relative humidity in the laboratory was maintained to preclude moisture loss from the sample. A horizontal displacement rate of $5 \times 10^{-3}$ $\mathrm{mm} / \mathrm{min}$ was used to preclude pore pressure build up during testing [24]. The Horizontal displacement and shear stress were recorded over time using an automated data acquisition system. The test was terminated around failure (after crossing the peak stress) and the sample removed from the shear box. Triplicate sub-samples were cored through the failure plane for suction measurement in the WP4-T potentiameter.

The compacted specimen at the maximum dry unit weight was used to obtain the saturated shear strength properties $\left(c^{\prime}\right.$ and $\left.\phi^{\prime}\right)$. The sample was flooded with water and gradually loaded to cancel the swelling deformations (no measured changes were found in soil volume) and to expedite saturation by pore air expulsion [30]. Confirmed through basic phase relationships using measured water content, sample saturation was achieved in about 2 weeks. The test samples were obtained from the saturated sample, and the above shear testing procedure was followed to ensure minimal moisture changes during the soil-shearing process.

\section{Results and discussion}

$G_{\text {s }}$ of the soil was found to be 2.75 which is typical of clays, that is, between 2.4 and 2.95 [61]. Likewise, the liquid limit $\left(w_{1}=75 \%\right)$ and plastic limit $\left(w_{\mathrm{p}}=25 \%\right)$ indicated a soil possessing high water adsorption capacity: the Ip was calculated to be 50\%. Overall, the soil classified as $\mathrm{CH}$ (inorganic clay of high plasticity).

Compaction pertains to the densification of soils by the application of mechanical energy [33]. Figure 4 shows the compaction curve for the investigated expansive soil with sample identified by numbers. The maximum dry unit weight was found to be $15.6 \mathrm{kN} / \mathrm{m}^{3}$ at the optimum water content of $24 \%$. The slightly higher maximum $\gamma_{\mathrm{d}}$ for the 


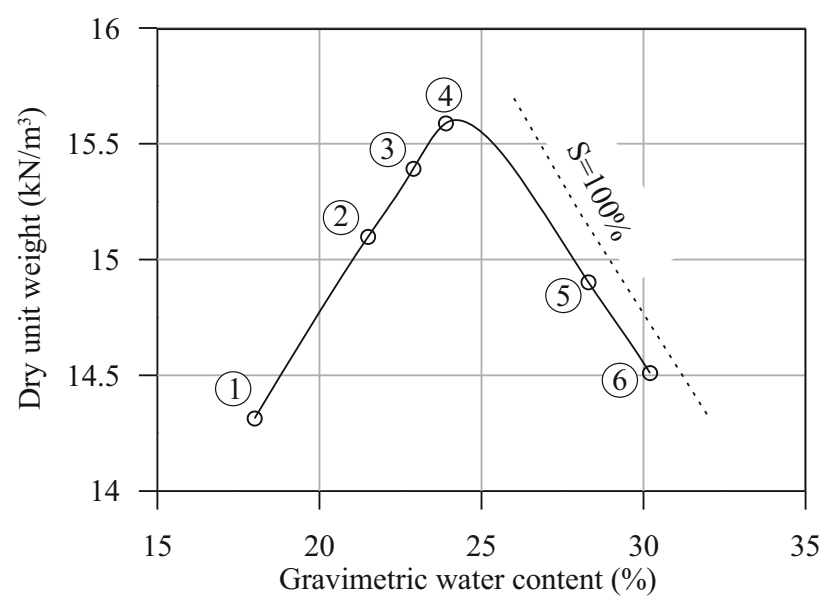

Fig. 4 Compaction curve for the investigated expansive soil

investigated clay compared to manual compaction results (14.2 [10] and $13.9 \mathrm{kN} / \mathrm{m}^{3}$ [21]) may be attributed to better control of compactive energy during mechanical compaction, used in the current study. Furthermore, the optimum water content was found to be about $90 \%$ of the plastic limit (25\%), which is similar to the results for cohesive soils [55]. The increase in $\gamma_{\mathrm{d}}$ with an increase in water content on the dry side of optimum is due to expulsion of air from the pore space and particle rearrangement that decreased the pore space. Conversely, the increase in water content, albeit a constant air content, on the wet side of optimum resulted in an increased volume of water which replaced the soil particles $\left(G_{\mathrm{s}}=2.75\right)$. In general, clays compacted on the dry side and up to the optimum are characterized by a clod-rich fabric [62], whereas those around the optimum and on the wet side possess a slightly clodded fabric [18].

The SWCC (amount of water in soil versus soil suction) correlates with the geotechnical properties, such as volume change and shear strength of unsaturated soils [22]. In general, saturated soils undergo desaturation with increasing suction up to the air entry value (AEV) when air starts to enter into the soil pores due to capillarity. The process continues rapidly up to the residual state beyond which high suction is required to remove the adsorbed water from clays; complete desiccation is achieved at $10^{6} \mathrm{kPa}$ suction. Figure 5 gives the SWCC of the investigated expansive clay. The SWCC showed one AEV of $10 \mathrm{kPa}$ [for $w$ and volumetric water content $(\theta)$ ] and two AEVs for $S$ : 10 and $7000 \mathrm{kPa}$ due to drainage through inter-clod pores and soil matrix, respectively. The corresponding residual suction from the first two SWCCs was found to be $7000 \mathrm{kPa}$ and almost 20,000 kPa from the last SWCC. The SWCCs based on water content are obtained using the water removed from the soil and are independent of volume changes (void ratio variations) in the soil. In contrast, the bi-modal

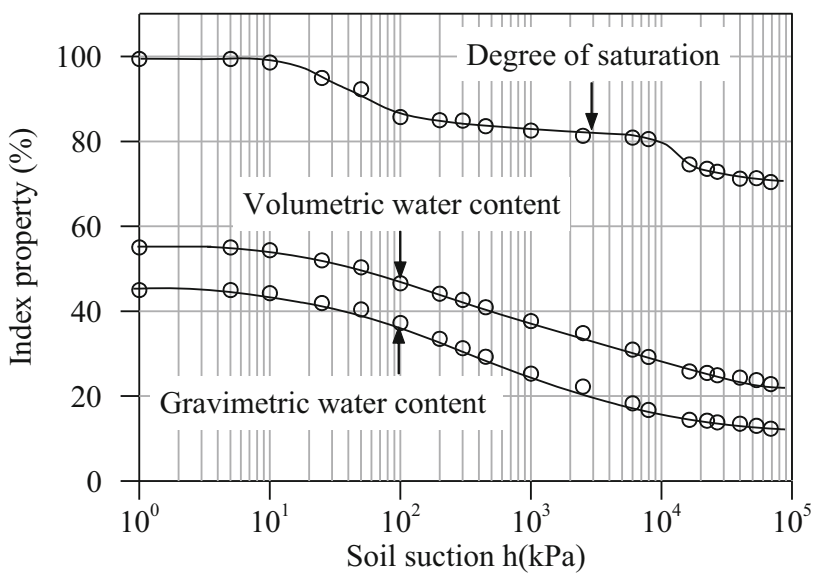

Fig. 5 Soil water characteristic curve for the investigated expansive soil

S-based SWCC includes the swelling-shrinking nature of expansive soils. In such soils, drainage through inter-clod voids results in localized compressibility due to capillarity that, in turn, ensures saturated conditions at high suction [42].

The shape of SWCC for expansive soils is governed by the index property on the $y$-axis. According to Azam and Chowdhury [10], the $w$-based curve is the mathematically accurate representation of SWCC for compacted expansive clays, because this index property is directly measured. Likewise, the $\theta$-based curve is useful for the determination of storage capacity using part of the curve between the matrix air entry value and residual suction [24]. As explained earlier in relation to Eq. 3, this curve is used to determine the unsaturated shear strength properties. Finally, the $S$-based curve is best suited to represent actual sample state, because this parameter captures the microand macrolevel soil structure [35].

The expansive nature of the soil required that SWCC be studied in conjunction with the shrinkage path [22]. Conceptually, such a curve is J-shaped showing a sloped line of decreasing void ratio and water content along $S=100 \%$ that joins a horizontal line at a constant void ratio at shrinkage limit. Compacted cohesive soils show departure from the saturation line as reported by Ho et al. [32] for glacial till and Tripathy et al. [63] for expansive soils. Figure 6 shows the shrinkage curve for the investigated expansive soil. Theoretical lines representing various degrees of saturation were obtained from basic phase relationships and using $G_{\mathrm{s}}=2.75$. Similar to the results of Azam and Chowdhury [10], the clay showed an S-shaped curve, such that most of the shrinkage occurred around $S \approx 80 \%$, whereas desaturation before and after this value were associated with small changes in void ratio.

Figure 7 gives the stress-horizontal displacement curves for the investigated expansive soil (the numbers pertain to 


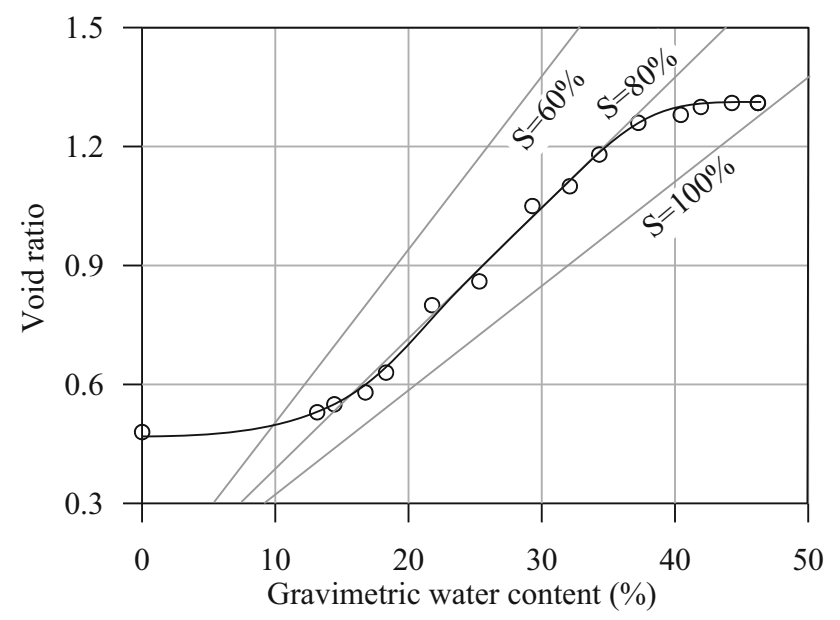

Fig. 6 Shrinkage curve for the investigated expansive soil

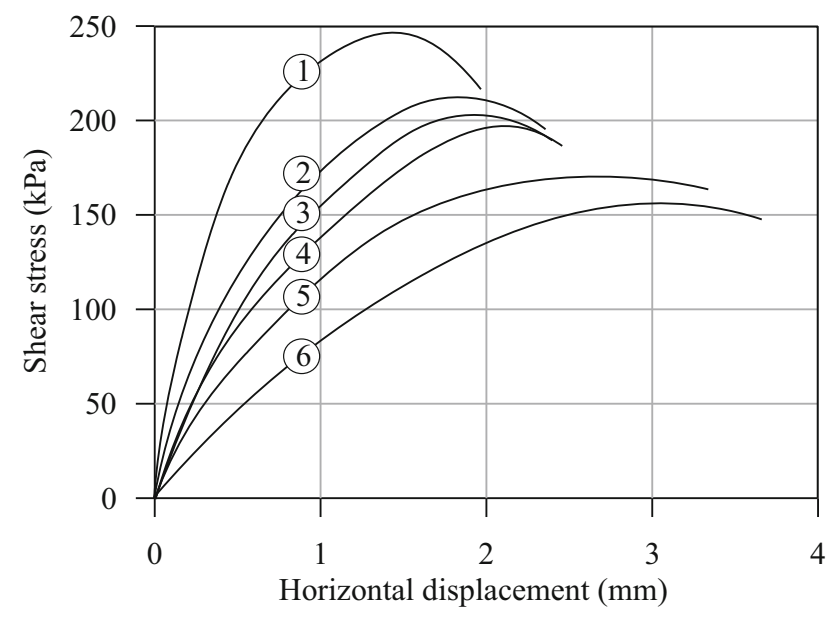

Fig. 7 Stress-strain relationships for the investigated expansive soil at $225 \mathrm{kPa}$ net normal stress

Table 2 Summary of initial conditions of the test samples

\begin{tabular}{llll}
\hline Sample ID & $w(\%)$ & $\gamma_{\mathrm{d}}\left(\mathrm{gm} / \mathrm{cm}^{3}\right)$ & $e$ \\
\hline 1 & 18.0 & 1.46 & 0.88 \\
2 & 21.5 & 1.54 & 0.78 \\
3 & 22.9 & 1.57 & 0.75 \\
4 & 23.9 & 1.59 & 0.72 \\
5 & 28.3 & 1.52 & 0.80 \\
6 & 30.2 & 1.48 & 0.85 \\
\hline
\end{tabular}

those in Fig. 4). The initial test conditions of the test samples are summarized in Table 2. Test data of samples at $225 \mathrm{kPa}$ net normal stress are shown to understand variations along the compaction curve. Samples on the dry side of optimum had high-peak stresses (200-250 kPa), lowhorizontal displacements (up to 0.02) at peak stress, and high-stress-displacement gradients $(12,250-13,350 \mathrm{kPa} /$ $\mathrm{mm})$. Conversely, samples on the wet side of optimum had low-peak stress (150-170 kPa), high-horizontal displacement (0.03), and low-stress-displacement gradients (5570-5670 kPa/mm). According to Holtz et al. [33], soils on the dry side have a random structure with larger clods (analogous to coarse grained particles) and soils on the wet side have an oriented structure with dispersed particles. The interlocked clods required a high stress to break and precluded horizontal displacement development thereby promoting a high modulus. Conversely, oriented clay particles slided past each other to generate a large horizontal displacement at a lower stress and, hence, a low-stressdisplacement gradient.

Figure 8 plots the shear strength properties with respect to increasing water content (regular scale) and decreasing soil suction (logarithmic scale in the opposite direction). Cohesion (Fig. 8a) increased from $24 \mathrm{kPa}$ (on dry side due to cohesion mobilization between the clods by water addition) to $65 \mathrm{kPa}$ (at optimum) and then decreased to $33 \mathrm{kPa}$ (on wet side due to the development of thicker adsorbed water films on clay particles). Similar to the findings of Cokca et al. [16], the cohesion versus water content plot for the investigated expansive soil closely followed the compaction curve. The above cohesion data again followed the trend of the compaction curve when plotted with respect to suction. The suction values reduced from 3900 (for $c=24 \mathrm{kPa}$ on dry side) to $1440 \mathrm{kPa}$ ( $c=65 \mathrm{kPa}$ at optimum) and then further reduced to $890 \mathrm{kPa}(c=33 \mathrm{kPa}$ wet side). Although a comparable cohesion trend over such a large suction range was not found for expansive soils, Estabragh and Javadi [20] reported a nonlinear increase in cohesion from 10 (at zero suction) to $75 \mathrm{kPa}$ (at $300 \mathrm{kPa}$ suction) for a compacted silt. For the investigated clay, it can be concluded that both cohesion trends strongly match the compaction curve for unsaturated expansive soils.

The friction angle (Fig. 8b) decreased from $44^{\circ}$ (on dry side due to interlocking between clay clods and clod/particle pulling together due to soil suction) to $29^{\circ}$ (at optimum) and to $27^{\circ}$ (on wet side due to increased lubrication and slippage along clod/particle boundaries). The friction angle versus water content plot for the investigated expansive soil exhibited an L-shaped trend. The is similar to the findings of Cokca et al. [16], who reported that friction angle for a compacted expansive clay decreased from $44^{\circ}$ to $20^{\circ}$ for a water content range of $18-28 \%$. The friction angle decreased by $15^{\circ}$ with a suction decrease of $2450 \mathrm{kPa}$ (from $3900 \mathrm{kPa}$ through $1450 \mathrm{kPa}$ ) up to the optimum beyond which a small decrease of $0.5^{\circ}$ with a suction decrease of $100 \mathrm{kPa}$ (from $990 \mathrm{kPa}$ through $890 \mathrm{kPa}$ ) was observed. These data correlate well with other published work on expansive soils. Merchan et al. [43] reported $21^{\circ}$ decrease in friction angle for high suction ranges $(1000 \mathrm{kPa}$ through $75,000 \mathrm{kPa})$, whereas Ye et al. 

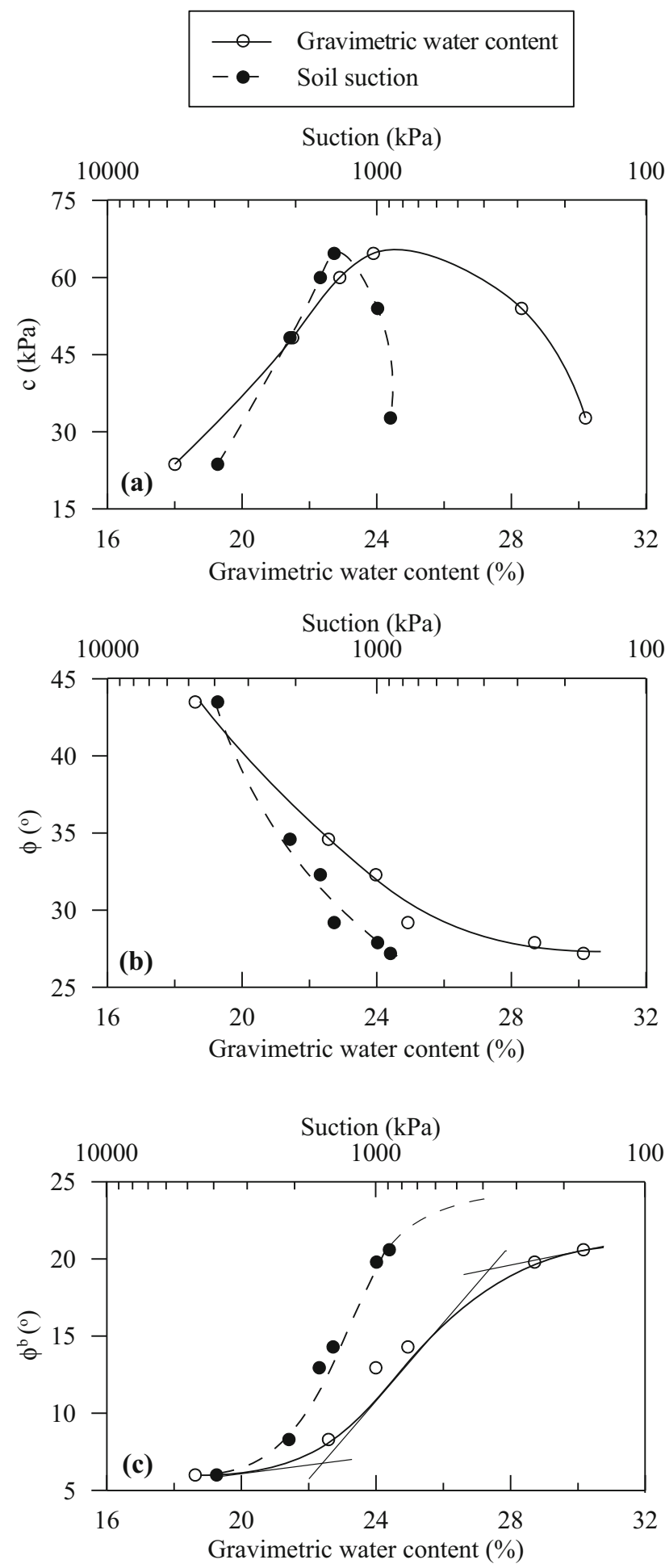

Fig. 8 Shear strength properties versus water content and soil suction for the investigated expansive soil

[68] showed that friction angle is a constant in the low suction range.

The friction angle due to suction (Fig. 8c) followed an S-shaped curve when plotted with respect to water content that was approximated using the following straight line portions: an initial low increase of up to $1^{\circ}$ (ranging from $6^{\circ}$ to $7^{\circ}$ ) on the dry side due to clod/particle pulling together under capillary action, an intermediate rapid increase of up to $12^{\circ}$ (ranging from $7^{\circ}$ to $19^{\circ}$ ) at a water content variation of $\pm 2 \%$ from the optimum similar to the reduction in stabilometer strength, used for embankment design, of compacted soils [33], and a low final increase of up to $2^{\circ}$ (ranging from $19^{\circ}$ to $21^{\circ}$ ) on the wet side that tends to approach $\phi$ because of close to saturation conditions. According to Gan and Fredlund [26], the soil pores are mostly filled with water under low suction values (extended portion beyond measured data in $\phi^{\mathrm{b}}$ versus suction curve in Fig. 8c). These voids gradually decrease in size with increasing suction because of changes in water menisci within the soil skeleton. The decreasing rate of pore size reduction during desaturation results in a nonlinear decrease in the value of $\phi^{\mathrm{b}}$ when plotted with respect to suction.

The suction range for the investigated compacted expansive clay was measured to be $890 \mathrm{kPa}$ through $3900 \mathrm{kPa}$. Using the SWCCs based on water content ( $w$ and $\theta$ ), this range approaches the AEV (10 kPa) on one side and the residual suction $(7000 \mathrm{kPa})$ on the other. Figure $8 \mathrm{c}$ indicates that the observed three-stage increase in $\phi^{\mathrm{b}}$ is in agreement with the SWCC, that is, small increase of $2^{\circ}$ when the sample approached AEV followed by a large increase of $12^{\circ}$ between AEV and residual suction and then by negligible increase of $1^{\circ}$ when the sample approached residual suction. The observed nonlinear variation of $\phi^{\mathrm{b}}$ with suction correlates well with the empirical functions for clayey soils [27, 65]. Likewise, the current study is in line with shear strength variation of unsaturated soils, summarized as follows [24]: (i) negligible change up to AEV; (ii) increase between AEV and residual conditions; and (iii) insignificant change beyond residual conditions.

Figure 9 plots friction angles due to suction $\left(\phi^{\mathrm{b}}\right)$ versus water content. For the investigated expansive clay, the measured data and the estimated values of $\phi^{\mathrm{b}}$ increased linearly with an increase in gravimetric water content. The high $R^{2}$ of 0.94 validates the measured data, thereby developing a simple approach for the determination of $\phi^{\mathrm{b}}$. The data scatter is attributed to the nonlinear decrease in the value of $\phi^{\mathrm{b}}$ with increasing suction, as described earlier. Furthermore, the SWCC (used for $\phi^{\mathrm{b}}$ estimation) was obtained on wet side of optimum with a dispersed fabric (orderly oriented particles) that is different from that on the dry side of optimum (randomly arranged particles). Therefore, the above scatter in the data is partly attributed to the gradually changing fabric along the compaction curve. 


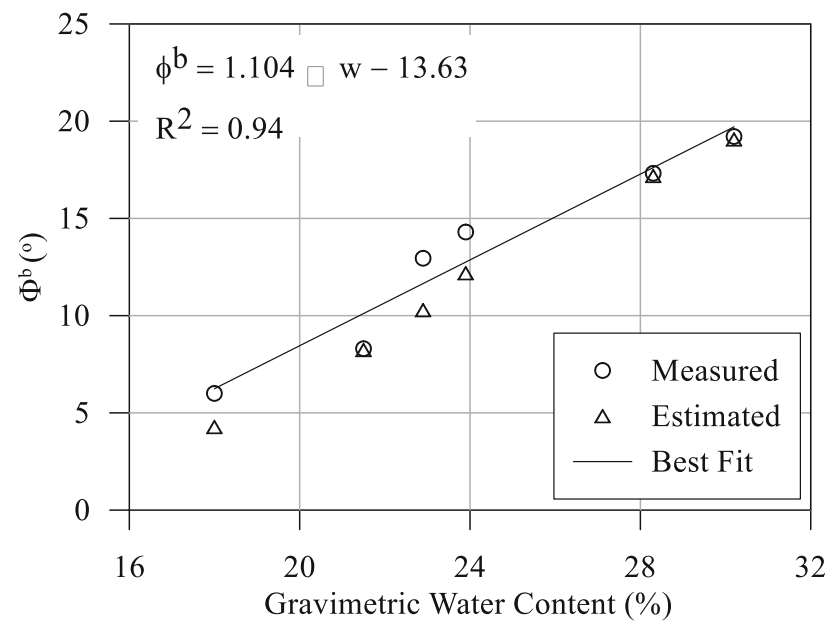

Fig. 9 Relationship between friction angle due to suction versus water content

\section{Summary and conclusions}

Knowledge of the shear strength properties of compacted expansive clays is pivotal for construction because of their relationships to stability of slopes and bearing capacity of foundations. Laboratory investigations on a typical expansive soil $\left(w_{1}=75\right.$ and $\left.w_{\mathrm{p}}=25 \%\right)$ were conducted using compacted samples. The main conclusions of this research are summarized as follows: the SWCC had one AEV of $10 \mathrm{kPa}$ for $w$ and $\theta$ and two AEVs for $S: 10$ and $7000 \mathrm{kPa}$ due to drainage through inter-clod pores and soil matrix, respectively. Most of the shrinkage was found to occur around $S \approx 80 \%$, whereas desaturation before and after this value were associated with small changes in void ratio. Likewise, the dry side peak stress and the initial gradient of up to $250 \mathrm{kPa}$ and $13,350 \mathrm{kPa} / \mathrm{mm}$, respectively, decreased to $170 \mathrm{kPa}$ and $5670 \mathrm{kPa} / \mathrm{mm}$ on the wet side. Cohesion matched the compaction curve and increased from $24 \mathrm{kPa}$ on dry side to $65 \mathrm{kPa}$ at optimum and then decreased to $33 \mathrm{kPa}$ on wet side. The friction angle followed an L-shaped trend and decreased from $44^{\circ}$ on dry side to $29^{\circ}$ at optimum and to $27^{\circ}$ on wet side. The S-shaped $\phi^{\mathrm{b}}$ curve comprised $1^{\circ}$ increase on dry side, $12^{\circ}$ increase around optimum, and $2^{\circ}$ increase on wet side that tended to approach $\phi$ near saturation. This three-stage increase in $\phi^{\mathrm{b}}$ is in agreement with the SWCC, that is, small increase when the sample approached AEV followed by a large increase between AEV and residual suction and then by negligible increase when the sample approached residual suction.

Acknowledgements The authors acknowledge the financial support from the Natural Science and Engineering Research Council of Canada and the laboratory space provided by the University of Regina.

\section{References}

1. ASTM D854-10 (2016) Standard test methods for specific gravity of soil solids by water pycnometer. Annual Book of ASTM Standards, West Conshohocken

2. ASTM D1452-09 Standard practice for soil exploration and sampling by Auger borings. Annual Book of ASTM Standards, West Conshohocken

3. ASTM D1557-12 Standard test methods for laboratory compaction characteristics of soil using modified effort $(56,000 \mathrm{ft}-\mathrm{lbf} /$ $\left.\mathrm{ft}^{3}\left(2,700 \mathrm{kN}-\mathrm{m} / \mathrm{m}^{3}\right)\right)$. Annual Book of ASTM Standards, West Conshohocken

4. ASTM D2216-10 Standard test methods for laboratory determination of water (moisture) content of soil and rock by mass. Annual Book of ASTM Standards, West Conshohocken

5. ASTM D2487-11 Standard practice for classification of soils for engineering purposes (unified soil classification system). Annual Book of ASTM Standards, West Conshohocken

6. ASTM D3080/D3080M-11 Standard test method for direct shear test of soils under consolidated drained conditions. Annual Book of ASTM Standards, West Conshohocken

7. ASTM D4318-10 Standard test methods for liquid limit, plastic limit, and plasticity index of soils. Annual Book of ASTM Standards, West Conshohocken

8. ASTM D4943-08 Standard test method for shrinkage factors of soils by the wax method. Annual Book of ASTM Standards, West Conshohocken

9. ASTM D6836-02 (2008) Standard test methods for determination of the soil water characteristic curve for desorption using a hanging column, pressure extractor, chilled mirror hygrometer, and/or centrifuge. Annual Book of ASTM Standards, West Conshohocken

10. Azam S, Chowdhury RH (2013) Swell-shrink-consolidation behavior of compacted expansive clays. Int J Geotech Eng 7:424-430

11. Bai FQ, Liu SH (2012) Measurement of the shear strength of an expansive soil by combining a filter paper method and direct shear test. Geotech Test J 35:451-459

12. Bao C, Gong B, Zhan L (1998) Properties of unsaturated soils and slope stability of expansive soils. In: Proceedings 2 nd international conference on unsaturated soils, Beijing, vol 1, pp 71-98

13. Bayin A, Iyisan R, Hatipoglu M, Cevikbilen G, Isik A (2013) The effect of testing methods on residual shear strength of cohesive soils. In: Proceeding 2nd international Balkans conference on challenges of civil engineering, Tirana, pp 769-776

14. Bishop AW, Alpan I, Blight GE, Donald I (1960) Factors controlling the shear strength of partly saturated cohesive soils. In: Research conference on shear strength of cohesive soils, Boulder, pp 503-532

15. Christiansen EA, Sauer EK (2002) Stratigraphy and structure of Pleistocene collapse in the Regina Low, Saskatchewan, Canada. Can J Earth Sci 39:1411-1423

16. Cokca E, Erol O, Armangil F (2004) Effects of compaction water content on the shear strength of an unsaturated clay. J Geotech Geol Eng 22:285-297

17. Culley RW, Duczek D (1983) Calcium chloride in subgrade and shoulder stabilization, Saskatchewan. Department of Highways and Transportations, Regina

18. Delage P, Audiguier M, Cui YJ, Michael DH (1996) Microstructure of a compacted silt. Can Geotech J 33:150-158

19. Escario V, Juca JFT (1989) Strength and deformation of partly saturated soils. In: Proceedings 12th international conference on soil mechanics and foundation engineering, Rio de Janeiro, vol 2, pp 43-46 
20. Estabragh AR, Javadi AA (2012) Effect of suction on volume change and shear behaviour of an overconsolidated unsaturated silty soil. J Geomech Eng 4:55-65

21. Fredlund DG (1964) Comparison of soil suction and one-dimensional consolidation characteristics of a highly plastic clay. MSc Thesis, Department of Civil Engineering, University of Alberta, Edmonton, Alberta

22. Fredlund DG, Houston SL (2013) Interpretation of soil water characteristic curves when volume change occurs as soil suction is changed. In: Proceedings 1st Pan-American conference on unsaturated soils, Cartagena de Indias, vol 1, pp 15-31

23. Fredlund DG, Morgenstern NR, Widger RA (1978) The shear strength of unsaturated soils. Can Geotech J 15:313-321

24. Fredlund DG, Rahardjo H, Fredlund MD (2012) Unsaturated soil mechanics in engineering practice. Wiley, New York

25. Fredlund DG, Rahandjo H, Gan JKM (1987) Nonlinearity of strength envelope for unsaturated soils. In: Proceedings 6th international conference on expansive soils, New Delhi, pp 49-54

26. Gan JKM, Fredlund DG (1988) Multistage direct shear testing on unsaturated soils. Geotech Test J 11:132-138

27. Gan JKM, Fredlund DG, Rahandjo H (1988) Determination of the shear strength parameters of an unsaturated soil using the direct shear test. Can Geotech J 25:500-510

28. Garven E (2009) Review of the empirical equations for predicting the shear strength of unsaturated soils. M.Sc. Thesis, University of Ottawa, Ottawa

29. Garven E, Vanapalli SK (2006) Evaluation of empirical procedures for predicting the shear strength of unsaturated soils. In: Proceedings 4th international conference on unsaturated soils, Carefree, pp 2570-2592

30. Hilf J (1948) Estimating construction pore pressures in rolled earth dams. In: Proceedings 2nd International Conference on Soil Mechanics and Foundation Engineering, Rotterdam, vol 3, pp 234-240

31. Ho DYF, Fredlund DG (1982) Multistage triaxial tests for unsaturated soils. Geotech Test J 5:18-25

32. Ho DYF, Fredlund DG, Rahardjo H (1992) Volume change indices during loading and unloading of an unsaturated soil. Can Geotech J 29:195-207

33. Holtz RD, Kovacs WD, Sheahan TC (2011) An introduction to geotechnical engineering. Pearson Education Ltd, New Jersey

34. Huat BBK, Ali FH, Hashim S (2005) Modified shear box test apparatus for measuring shear strength of unsaturated residual soil. Am J Appl Sci 2:1283-1289

35. Ito M, Azam S (2013) Engineering properties of a vertisolic expansive soil deposit. Eng Geol 152:10-16

36. Ito M, Azam S (2010) Determination of swelling and shrinkage properties of undisturbed expansive soils. Geotech Geol Eng 28:413-422

37. Katte V, Blight G (2012) The roles of solute suction and surface tension in the strength of unsaturated soil. In: Mancuso C, Jommi C, D’Onza F (eds) Unsaturated soils: research \& applications, no (2). Springer-Verlag, Germany, pp 431-437

38. Khalili N, Khabbaz MH (1998) A unique relationship for the determination of the shear strength of unsaturated soils. Geotechnique 48:681-687

39. Kong LW, Tan LR (2000) Study on shear strength and swellingshrinkage characteristic of compacted expansive soil. In: Proceedings 1st International Conference on Unsaturated Soils for Asia, Singapore, vol 1, pp 515-519

40. Leong EC, Tripathy S, Rahardjo H (2003) Total suction measurement of unsaturated soils with a device using the chilledmirror dew-point technique. Geotechnique 53:173-182

41. Leroueil S, Hight DW (2013) Compacted soils: from physics to hydraulic and mechanical behaviour. Proceedings 1st Pan-
American conference on unsaturated soils, Cartagena de Indias, vol 1, pp 41-59

42. Marinho FMA (2005) Nature of soil-water characteristic curve for plastic soils. J Geotech Geoenviron Eng 131:654-661

43. Merchan V, Vaunat J, Romero E, Meca T (2008) Experimental study of the influence of suction on the residual friction angle of clays. In: Proceeding of the 1st European conference on unsaturated soils, Durham, pp 423-428

44. Miao L, Houston SL, Cui Y, Yuan J (2007) Relationship between soil structure and mechanical behavior for an expansive unsaturated clay. Can Geotech J 44:126-137

45. Miao L, Songyu L, Yuanming L (2002) Research of soil water characteristics and shear strength features of Nanyang expansive soil. Eng Geol 65:261-267

46. Nam S, Gutierrez M, Diplas P, Petrie J (2011) Determination of the shear strength of unsaturated soils using the multistage direct shear test. Eng Geol 122:272-280

47. Ng CWW, Cui YJ, Chen R, Delage P (2007) The axis translation and osmotic techniques in shear testing of unsaturated soils: a comparison. Soils Found 47:674-684

48. Oberg A, Sallfors G (1997) Determination of shear strength parameters of unsaturated silts and sands based on the water retention curve. Geotech Test J 20:40-48

49. Panesar HS, Kelly AJ, Yoshida RT, Clifton AW (2010) Real time monitoring for embankment constructed overtop of Regina clay. In: Proceedings 63rd Canadian Geotechnical Conference, Calgary, pp 382-389

50. Prakash K, Shidharan A, Baba JA, Thejas HK (2008) Determination of shrinkage limit of fine-grained soils by wax method. Geotech Test J 32:86-89

51. Rahadrjo H, Heng OB, Leong EC (2004) Shear strength of a compacted residual soil from consolidated drained and constant water content triaxial tests. Can Geotech J 41:421-436

52. Rassam D, Cook F (2002) Predicting the shear strength envelope of unsaturated soils. Geotech Test J 25:215-220

53. Sedano JAI, Vanapalli SK, Garga VK (2007) Modified ring shear apparatus for unsaturated soils testing. Geotech Test J 30:39-47

54. Shanker BN, Saikrishna V, Reddy GN (1989) Effect of drainage conditions on shear strength of swollen expansive soils. In: Proceedings indian geotechnical conference, Bombay, pp 247-249

55. Sridharan A, Nagaraj HB (2005) Plastic limit and compaction characteristics of fine grained soils. Ground Improv 9:17-22

56. Sorensen KK, Okkels N (2013) Correlation between drained shear strength and plasticity index of undisturbed overconsolidated clays. In: Proceedings of the 18th international conference on soil mechanics \& geotechnical engineering, Paris, pp 423-428

57. Stark TD, Hussain M (2013) Empirical correlations: drained shear strength for slope stability analyses. J Geotech Geoenviron Eng 139:853-862

58. Sweeney DA (1988) The effect of lime on the properties of regina clay. M.Sc. Thesis, University of Saskatchewan, Saskatoon

59. Taha MR, Hossain MK, Mofiz SA (2000) Effect of suction on the strength of unsaturated soil. In: Proceedings Geo-Denver, Denver, vol 287, pp 210-221

60. Tekinsoy MA, Kayadelen C, Keskin MS, Söylemez M (2004) An equation for predicting shear strength envelope with respect to matric suction. Comput Geotech 31:589-593

61. Terzaghi K, Peak RB, Mersi G (1996) Soil mechanics in engineering practice. Wiley, New York

62. Toll DG (2000) The influence of fabric on the shear behavior of unsaturated compacted soils. ASCE Geotech Special Publ 99:222-234

63. Tripathy S, Subba Rao KS, Fredlund DG (2002) Water contentvoid ratio swell-shrink paths of compacted expansive soils. Can Geotech J 39:938-959 
64. Vanapalli SK, Fredlund DG (2000) Comparison of different procedures to predict unsaturated soil shear strength. In: Proceedings geo-denver conference 2000, Denver, pp 195-209

65. Vanapalli SK, Fredlund DG, Pufahl DE, Clifton AW (1996) Model for the prediction of shear strength with respect to soil suction. Can Geotech J 33:379-392

66. Widger RA, Fredlund DG (1979) Stability of swelling clay embankment. Can Geotech J 16:140-151
67. Yang H, Xiao J, Wang S, Zuo W (2009) Study on the determination of residual shear strength for expansive soil. In: Proceeding GeoHunan International Conference, Changsha, pp 49-54

68. Ye WM, Zhang YW, Chen B, Zhou X, Xie Q (2010) Shear strength of an unsaturated weakly expansive soil. J Rock Mech Geotech Eng 2:155-161

69. Zhan TLT, Ng CWW (2006) Shear strength characteristics of an unsaturated expansive clay. Can Geotech J 43:751-763 